\title{
Demographic Factors and Communal Mastery as Predictors of Academic Motivation and Test Anxiety
}

\author{
M. Hülya Ünal-Karagüven \\ Correspondence: M. Hülya Ünal-Karagüven, Education Faculty, Department of Educational Sciences, Marmara \\ University, 34722, Istanbul, Turkey
}

Received: January 27, 2015

Accepted: February 12, 2015 Published Online: March 16, 2015

doi:10.11114/jets.v3i3.648

URL: http://dx.doi.org/10.11114/jets.v3i3.648

\begin{abstract}
Academic motivation and test anxiety have been still adduced for low performance of students by educators. To know the factors that have an effect on students' academic motivation and test anxiety levels can be helpful to improve students' academic performance. The aim of this study was to investigate the effects of demographic variables and communal mastery as predictors of academic motivation and test anxiety levels based on the self-determination theory. Study group consisted of 336 Turkish high-school students. Academic Motivation Scale, Test Anxiety Inventory, Communal Mastery Scale and a questionnaire were used $(\mathrm{n}=64)$. Multiple correlation analyses and hierarchical multiple regression were used to predict variables' effects on academic motivation and test anxiety. Results were discussed in terms of self-determination theory. Correlation analyses partly confirmed and partly disconfirmed study's hypotheses. Communal mastery was positively associated, with perceived academic achievement while test anxiety and amotivation were negatively associated with perceived academic achievement. Gender, school type, parents' education levels, having siblings, having a computer and communal mastery were partly negatively and partly positively associated with academic motivation and test anxiety. Perceived academic achievement was negatively associated with test anxiety and amotivation. Multi levels analyses results showed that demographic factors and communal mastery were significant predictors of high-school students' academic motivation and test anxiety levels.
\end{abstract}

Keywords: academic motivation, test anxiety, communal mastery, demographic variables, high-school students

\section{Introduction}

Despite different methods and modern technology used in the classrooms, poor academic performance is still very common among students. Particularly, two variables, motivational problems and test anxiety have been adduced for poor performance of students by teachers and educators (Simons, 1974; Akbaş \& Kan, 2007; Hardre \& Sullivan, 2009). Low academic performance, motivational problems and test anxiety have been indicated as the most prominent student relevant issues in today's classrooms by teachers and school counselors (Uzbaş, 2009). The determination of effective risk factors on students' academic motivation and test anxiety levels can be helpful to raise academic performance. The aim of this study is to identify the factors that have an effect on a group of high-school students' academic motivation and test anxiety levels in the based on Deci and Ryan's (1985) Self-determination theory.

According to Harris (1940) degree of motivation was one of the most essential factors in academic achievement. Since the thirties motivation has been determined to play an important role in learning. House (1993) has suggested that motivation has a significant effect on academic achievement. Hence, it has been a central subject for psychology and education studies to improve student academic performance (Entwistle, 1968; Eysenck, 1970; Frymier, 1975; Boekaerts, 1996; Roeser, Strobel \& Quihuis, 2002; Howey, 2008). There are many definitions of motivation in the literature.

Motivation comes from the Latin word "moveo", meaning that to move, stir, agitate, provoke or effect and cause movement (http://encyclopedia.thefreedictionary.com/motivation). Motivation is generally defined as the force that accounts for the arousal, selection, direction, and continuation of behavior. Motivation means the desire and willingness to do something or an internal drive that activates behavior and gives it direction. It is a drive that compels an individual to act towards the attainment of some goal. As defined by Daft (1977: 526), "Motivation refers to the forces either within or external to a person that arouses enthusiasm and persistence to pursue a certain course of action". Woolfolk (2004: 350) defined motivation as "an internal state that arouses, directs, and maintains behavior". Thorkildsen and his colleagues (2002: xi) defined motivation as "an internal force that activates, guides, and maintains behavior overtime" 
and asserted that motivation comprises of some multidimensional systems that guide individuals' willingness to approach and avoid particular tasks. Motivation is generally described as the process of promotion and sustains towards an intentional activity in psychology (Pintrich \& Schunk, 2002). All researchers agree to the one generic definition of motivation, which is a mental state that stimulates the behavior and arouses goal-oriented desire in human mind.

Researchers also agree that academic achievement related motivation involves a rather complicated set of issues. In related studies, academic motivation has been found positively associated with academic achievement, academic performance and 'will to learn' (Entwistle, 1968; Frymier, 1975). For educational settings, drive or degree of motivation has been refined to academic achievement motivation and is also known to be an important predictor for cognitive performances (Atkinson 1964; Atkinson \& Feather 1964; McClelland et al., 1953; Pintrich \& De Groot, 1990). The results of Oliver and Simpson's (1988) academic self-concept and motivation relevant study suggests that motivation predicts academic achievement.

These kinds of results emphasize that academic motivation is one of the basic factors for academic performance. It is described as "the cognitive, emotional, and behavioral indicators of students' investment in and attachment to education" (Tucker, Zayco \& Herman, 2002; 477). Academic motivation is also known as an academic engagement in practically and identified as the most influential of all the factors that affect student performance (Francis et al., 2004). Moreover, it is suggested that academic motivation is the only factor that directly impacts academic achievement; all other factors affect performance through their effect on motivation (Tucker, Zayco, \& Herman, 2002; 477). Different factors influence development and the use of motivation strategies of students. One such factor is the student's perceived self-efficacy which is defined as people's beliefs about their capabilities (Barron \& Harackiewicz, 2001; Elliot, \& Thrash, 2001).

Self-efficacy determines how people feel, think, motivate themselves and behave. Such beliefs produce these diverse effects through four major processes; cognitive, motivational, affective and selection processes (Bandura, 1997). Analyses revealed that, self-efficacy was the best predictors of performance (Pintrich \& De Groot, 1990). The examination of a group of students' self-efficacy levels indicated that low self-efficacy have been quite widespread among high-school students (Aksan \& Koçyiğit, 2011). This result indicates motivational problems, as well.

Another factor is the student's perception of themselves as being intrinsically or extrinsically motivated to engage in learning activities within educational environments (Barron \& Harackiewicz, 2001; Elliot, \& Thrash, 2001). According to self-determination theory (Deci \& Ryan, 1985), there has been a dialectical relation between people, as innately active organisms, and the social environment. In this theory, humans are assumed to be active, growth-oriented organisms that have an innate desire for stimulation and learning from birth, which is either supported or discouraged within their social environment (Deci \& Ryan, 1985, 2000). Within the social environment, people attempt to satisfy their three basic needs. These three innate or fundamental psychological needs are competence, autonomy and relatedness (Ryan \& Deci, 2000). In this theory, at the end of the interaction between these needs and the environment, three specific types of motivation are differentiated. Firstly, intrinsic motivation; the drive to pursue an activity simply for the pleasure or satisfaction derived from it, secondly; extrinsic motivation; pursuing an activity out of a sense of obligation, or as a means to an end, thirdly; amotivation; the absence of intent or drive to pursue an activity due to one's failure to establish contingencies between the activity and their behavior (Deci \& Ryan, 1985; 2000). Additionally, four types of extrinsic motivation have been distinguished by Deci and Ryan (1985): external regulation, introjected regulation, identified regulation and integrated regulation. These four types of extrinsic motivation show differences in the degree of self-determination that the individual associates with the behavior. More internalized or more integrated behaviors produce a greater sense of self-determination.

Based on one of the propositions that intrinsic motivation may be driven by specific, differentiated factors (Deci, 1975); three types of intrinsic motivation have been added to this original theory by Vallerand et al. (1992). Firstly, to know; the desire to perform an activity for the enjoyment one receives while learning new things. Secondly, to accomplish; the desire to perform an activity for the satisfaction one receives from accomplishing or creating new things. Thirdly, to experience stimulation; the desire to perform an activity for the experience one receives while experiencing sensory stimulation, which may reflect either intellectual or physical sensations (Vallerand et al., 1992). Thus, academic motivation can be examined within eight subtitles. Vallerand and his coworkers (1992) developed a scale that measures seven subtitles of academic motivation on the basis of the Self-Determination Theory and called the Academic Motivation Scale (AMS). Researchers have suggested that more intrinsically motivated individuals have better psychological well-being and derive more satisfaction out of a number of life's activities. Moreover, they employ deeper-level processing strategies and perform better academically (Grolnick \& Ryan, 1989; Miserandino, 1996; Ryan \& Deci, 2000). Hence, academic motivation has to be studied by separating it as intrinsic and extrinsic, as in this study.

Test anxiety is the other factor has been adduced for poor academic performance. It is generally accepted that it has a 
detrimental effect on test performance. A considerable number of theoretical and empirical studies have investigated the relationship among test anxiety and academic performance (Simons, 1974; Simons \& Bibb, 1974; Sarason, 1984; Pintrich \& De Groot, 1990; Eysenck \& Calvo, 1992; Stöber, 2004; Stöber \& Pekrun, 2004; Pekrun, et al., 2004; Putwain, 2008; Ergene, 2011, Balogun, 2014). Studies validated the importance of test anxiety as an effective factor for academic achievement (Simons \& Bibb, 1974; Hagtvet \& Benson, 1997; Stöber, 2004, Hürsen \& Tekman, 2014). Detrimental effects of test anxiety on knowledge acquisition as well as performance can occur by interfering with students' motivational tendencies and the use of effective cognitive and learning strategies (Hancock, 2001). Test anxiety involves a combination of physiological over-arousal, nervousness, worry and apprehension about test performance and often interferes with normal learning and lowers test performance. Test anxiety individually varies in duration and also in intensity (Speilberger, 1979) and is comprised of at least two main components; worry and emotionality (Liebert \& Morris, 1967). Sarason (1984) proposed that worrisome thoughts interfere with attention and therefore, reduce available cognitive resources. On the other hand, Eysenck (1992) argues that the negative influence of anxiety is overestimated. Moreover, if subjects become aware that their performance is not good, worry might increase motivation and enhance their performance. Bembenutty et al. (1998) found definite relationships between students' test anxiety and self-regulated motivation levels. All these arguments show that test anxiety can be studied together with academic motivation.

As indicated that, the social environment plays an important role in motivation; "social contexts either stifle or promote intrinsic motivation" (Deci \& Ryan, 2000; 262). Motivation may be mediated by individual differences in social competence and mastery. As a form of social competence, communal mastery was defined as the belief that one is capable of successful goal attainment by virtue of being closely interconnected with others (Hobfoll, Schroder, Wells \& Malek, 2002). A communal mastery scale was developed by the same researchers and has been used in different studies. In one of these studies, communal-mastery was found to be more effective than self-mastery for a group of Native American women, especially when faced with high-stress circumstances (Hobfoll et al., 2002). In a different study, for adolescent substance use, communal-mastery was determined as an important factor (Piko, 2006). It was intended to investigate the effects of communal mastery as predictors of academic motivation and test anxiety for high-school students in this study.

Demographic variables are likely the most documented variable as a predictor of test anxiety and academic motivation. For example; Simons (1974) found that test anxiety was a significant factor in underachieving males. The effects of gender as a predictor investigated for the motivation of chemistry lesson by Akbas and Kan (2007) in a different study. Parental education levels, as well as parental involvement, significantly impacts their children's academic motivation. Many studies have suggested that parental education levels transmit certain beliefs about the importance of an education and academic achievement during their school careers. Parental education-levels may not always directly affect their children's performances; however, these levels do tend to play a strong indirect role in the way that children are raised (Georgiou, 1999). According to Georgiou (1999) parents with higher degrees of education are typically more involved in their children's academic careers, thereby placing more emphasis on academics than those parents with lower degrees of education and less involvement in their children's education. The current study intended to examine the level of parental education level as a predictor of students' academic motivation. Having siblings is another factor to investigate its effects on motivation and test anxiety. This is due to fact that single children do not have siblings with whom to interact and to motivate each other, and thus, their academic motivation and test anxiety levels can be affected by this situation. Having technology such as computer can be a motivational factor for students. In the studies of Çeliköz (2009) studies, it was reported that motivation levels of a group of university students were affected by these kinds of demographic factors. The last demographic factor examined in this study was academic achievement. As mentioned earlier, the relationship between academic motivation and academic achievement is a complicated issue. This study intended to investigate the effects of academic achievement on academic motivation and test anxiety. The identification of risk factors for academic motivation and test anxiety can be useful to improve students' academic performance.

The current study intended, to investigate the effects of communal mastery and demographic factors as predictors of academic motivation and test anxiety levels of a group of high-school students in the based on Deci and Ryan's (1985) self-determination theory. This study may contributive to the performance of an integrated study with all the possible basic factors, which affects academic motivation and test anxiety. The research question is how these variables relate to academic motivation and test anxiety in higher education.

The hypotheses and research questions for this study were as follows:

1) Communal mastery is an important factor for academic motivation. (Will communal mastery be related to academic motivation subscales?) 
2) Communal mastery is also an important factor for test anxiety. (Will communal mastery be related to test anxiety subscales?)

3) Demographic variables are important factors for academic motivation. (Will demographic variables be related to academic motivation subscales?)

4) Demographic variables are important factors for test anxiety. (Will demographic variables be related to test anxiety subscales?)

5) Demographic variables will be one of several variables impacting academic motivation and test anxiety. (Will demographic variables have primary importance and account for greater variance than other variables such as communal mastery?)

\section{Method}

\subsection{Participant Characteristics}

The research was conducted with 336 seniors from a high-school. At the beginning, study group consisted of 340 seniors and later four of them were alimented due to the missing values. The average age was 18 years (range 17-20 years). $51 \%$ of the participants were male and $49 \%$ were female. Participants were administered test batteries, which are consisted four instruments on different pages. Participation was arranged voluntarily, with informed consent in the classroom environment. Students were recruited without regard to gender. Instructions were read aloud before students began responding by trained proctors. Sufficient time was given to all students to complete each instrument. This sample may be considered as a very representative one of the high-school students.

\subsection{Measures}

\subsubsection{Questionnaire}

Demographic characteristics were determined by a questionnaire. This questionnaire included questions relating to gender, parental education levels, having siblings, having a computer and academic performance $(\mathrm{n}=6)$. For example; perceived level of academic performance was assessed via an ordered scale: 1-Above Average, 2-Average, 3-Below Average. Parental education level were separately addressed for the father's and mother's highest educational degree. Parental education levels were analyzed as: 1-Primary School, 2-Secondary School, 3-High-school, 4-University, 5-Graduate School. In total, test batteries were consisted of one questionnaire and three scales $(n=64)$.

\subsubsection{Academic Motivation Scale (AMS)}

The AMS (Vallerand et al., 1992; Ünal-Karagüven, 2012) consists of 28 items and seven subscales; reflecting one subscale of amotivation, three subscales of intrinsic motivation and three subscales of extrinsic motivation. The seven subscales were: Intrinsic Motivation to Know (IMTK), Intrinsic Motivation to Accomplish (IMTA), Intrinsic Motivation to Experience Stimulation (IMES), Extrinsic Motivation External Regulation (EMER), Extrinsic Motivation Introjected Regulation (EMIN), Extrinsic Motivation Identified Regulation (EMID) and Amotivation (AMOT). The items are rated on a seven-point scale, ranging from 1 (does not correspond at all) to 7 (corresponds exactly). Each subscale consists of four items; thus subscale scores can range from four to twenty-eight. A high score on a subscale indicates high endorsement of that particular aspect of academic motivation. All 28 items and seven subscales were used in this study, and Cronbach's alpha was $0.87(\mathrm{n}=28)$ for this group.

\subsubsection{Test Anxiety Inventory (TAI)}

The Turkish form of the Test Anxiety Inventory (Speilberger, 1980; Öner, 1990) was used in order to assess test anxiety. The scale consists of 20 items or statements. Respondents indicate how frequently they experience specific anxiety symptoms in an examination situation on a four-point scale from 1 (not at all) to 4 (very much so). The STE provides three scores; a total score, a worry sub-score and emotionality sub-score. Eight of the items measure the worry component and twelve of the items measure the emotionality component. The total score consisted of both subscales. In this study, Cronbach's alpha was 0.93 for total scores, $0.85(n=8)$ for worry and $0.89(n=12)$ for emotionality sub-scores.

\subsubsection{Communal Mastery Scale (CMS)}

Communal mastery assessed via the CMS (Hobfoll, Schröder, Wells \& Malek, 2002; Ünal-Karagüven, 2013) which was developed from two commonly employed measures of mastery (Pearlin et al., 1981) and self-efficacy (Schwarzer 1993). The scale consists of 10 items. Responses were based on a four-point scale from 1 (strongly disagree) to 4 (strongly agree). Students were asked to indicate the degree to which they agreed with the statements. For example, "With the help of those close to me, I have more control over my life" or "I can meet my goals by helping others meet theirs". Cronbach's alpha was $0.69(\mathrm{n}=10)$ in this study. 


\section{Results}

Data were analyzed through various procedures. First, Pearson product-moment correlation coefficients were calculated among all variables. The results indicated several positive and significant correlations. Lastly, a series of multiple regression analyses was conducted to investigate the relationships between independent and dependent variables.

Table 1. Means, standard deviations and Pearson bivariate correlations among variables ( $\mathrm{N}=336)$

\begin{tabular}{|c|c|c|c|c|c|c|c|c|c|c|c|c|c|c|c|c|c|}
\hline & Mean & $\mathrm{SD}$ & 1 & 2 & 3 & 4 & 5 & 6 & 7 & 8 & 9 & 10 & 11 & 12 & 13 & 14 & 15 \\
\hline 1. IMTK & 20.22 & 5.56 & & & & & & & & & & & & & & & \\
\hline 2. IMTA & 16.41 & 5.38 & $.554 * *$ & & & & & & & & & & & & & & \\
\hline 3. IMES & 15.73 & 4.99 & .462 & $.571 * *$ & & & & & & & & & & & & & \\
\hline 4. EMER & 21.57 & 5.46 & $.634 * *$ & $.306 * *$ & $.290 * *$ & & & & & & & & & & & & \\
\hline 5. EMIN & 16.82 & 6.03 & $.436 * *$ & $.690 * *$ & $.468 * *$ & $.317 * *$ & & & & & & & & & & & \\
\hline 6. EMID & 20.91 & 4.88 & $.434 * *$ & $.315 * *$ & $.125^{*}$ & $.625^{* *}$ & $.400 * *$ & & & & & & & & & & \\
\hline 7. AMOT & 10.09 & 6.22 & $-.133 *$ & $.287 * *$ & $.380 * *$ & $-.277 * *$ & $.274 * *$ & $-.195^{* *}$ & & & & & & & & & \\
\hline 8. Worry & 15.99 & 5.51 & .039 & $.117 *$ & $.144 * *$ & .004 & $.110 *$ & .008 & $.207 * *$ & & & & & & & & \\
\hline 9. Emotional. & 24.58 & 8.85 & .026 & $.124 *$ & $.130^{*}$ & .011 & $.110^{*}$ & .042 & $.164^{* *}$ & $.851 * *$ & & & & & & & \\
\hline 10.Com. Mast. & 27.58 & 4.60 & $.137^{*}$ & .027 & .021 & $.178 * *$ & .021 & .030 & $-.200 * *$ & $-.178 * *$ & $-.156 * *$ & & & & & & \\
\hline 11. Gender & & & .034 & .009 & .019 & $-.117^{*}$ & .033 & -.100 & $.246^{* *}$ & .003 & -.057 & .010 & & & & & \\
\hline 12. Mother Edu. & & & -.080 & -.022 & .081 & $-.124 *$ & .042 & -.049 & $.236^{* *}$ & $.108 *$ & $.112 *$ & -.016 & $.192 * *$ & & & & \\
\hline 13. Father Edu. & & & $-.142 * *$ & -.033 & .023 & $-.183 * *$ & .007 & $-.138 *$ & $.158 * *$ & .008 & $.139 *$ & -.074 & $.160^{* *}$ & $.552 * *$ & & & \\
\hline 14.Having Sibl. & & & .104 & .076 & -.058 & .059 & .045 & .017 & $-.191 * *$ & $-.166 * *$ & $-.149 * *$ & $.123^{*}$ & -.092 & $-.181 * *$ & $-.112 * *$ & & \\
\hline 15. Having Co. & & & $-.123^{*}$ & -.076 & $-.125^{*}$ & $-.124 *$ & -.072 & -.050 & .065 & -.047 & -.019 & .021 & $.109 *$ & .089 & $.140 *$ & $-.188 * *$ & \\
\hline 16. Acad. Ach. & & & .061 & -.037 & -.085 & .105 & -.005 & .002 & $-.110 *$ & $-.186 * *$ & $-.221 * *$ & $.166^{* * *}$ & -.102 & -.017 & -.022 & .050 & -.014 \\
\hline
\end{tabular}

** Correlation is significant at the 0.01 level (2-tailed).

* Correlation is significant at the 0.05 level (2-tailed).

Table 1 shows sample sizes, means, standard deviations and intercorrelations among variables used in the study. As seen in columns 1, 4 and 7, the relation to the first hypothesis, communal mastery significantly correlated with three academic motivation subscales; IMTK ( $r=0.137, \mathrm{p}<.05)$, EMER $(\mathrm{r}=0.178, \mathrm{p}<.01)$ and AMOT $(\mathrm{r}=0.200, \mathrm{p}<.01)$. Relating to the second hypothesis, communal mastery correlated positively and significantly with test anxiety sub scores. As seen in line 10 , column 8,9 , communal mastery negatively and significantly correlated with worry $(\mathrm{r}=-.178, \mathrm{p}<.01)$ and emotionality $(\mathrm{r}=0.178, \mathrm{p}<.01)$. Additionally, as seen in Table 1 , almost all seven academic motivation subscales were mostly positively and significantly $(\mathrm{p}<.01)$ correlated with each other except IMTK and IMES $(\mathrm{r}=0.462)$. Two test anxiety subscales were positively and significantly correlated with each other $(\mathrm{r}=0.851, \mathrm{p}<.01)$ as well, as seen in Table 1 , column 8 .

Hierarchical multiple regression was used to predict intrinsic motivation, extrinsic motivation, worry and emotionality from two blocks of predictor variables in relation to the third research question. Table 2 depicts these results. As seen in Table 2, academic motivation and test anxiety subscales were separately regressed on the two blocks of predictor variables; communal mastery and demographic characteristics. The following comments are offered, in summary;

An examination of Table 2 reveals that in the first column, all two predictor blocks accounted for $7.4 \%$ of IMTK variance. The predictor blocks separately accounted for the following percentages of IMTK: $1.9 \%$ by communal mastery and $5.5 \%$ by demographic characteristics. Of all demographic predictor variables, only the father's education variable accounted for a statistically significant portion of IMTK variance. 
Table 2. Hierarchical regression analysis for academic motivation and test anxiety. Dependent Variables: academic motivation and test anxiety. Independent variables: Communal mastery and demographic characteristics.

\begin{tabular}{|c|c|c|c|c|c|c|c|c|c|}
\hline Variables & $\begin{array}{l}\text { I. IMTK } \\
\text { beta }\end{array}$ & $\begin{array}{c}\text { II. IMTA } \\
\text { beta }\end{array}$ & $\begin{array}{c}\text { III. IMES } \\
\text { beta }\end{array}$ & $\begin{array}{l}\text { IV. EMER } \\
\text { beta }\end{array}$ & $\begin{array}{l}\text { V. EMIN } \\
\text { beta }\end{array}$ & $\begin{array}{l}\text { VI. EMID } \\
\text { beta }\end{array}$ & $\begin{array}{l}\text { VII. AMOT } \\
\text { beta }\end{array}$ & $\begin{array}{c}\text { VIII. Worry } \\
\text { beta }\end{array}$ & $\begin{array}{c}\text { IX. Emot. } \\
\text { beta }\end{array}$ \\
\hline \multicolumn{10}{|l|}{ Group 1: } \\
\hline Communal M. & $.120 * *$ & .027 & .021 & $.178 * * *$ & .021 & .030 & $-.200 * * *$ & $-.178 * * *$ & $-.156^{* *}$ \\
\hline $\mathbf{R}^{2}$ & $.019 * *$ & .001 & .001 & $.032 * * *$ & .001 & .001 & $.040 * * *$ & $.032 * * * *$ & $.024 * *$ \\
\hline \multicolumn{10}{|l|}{$\begin{array}{l}\text { Group 2: dem. } \\
\text { characteristics }\end{array}$} \\
\hline Gender & .070 & -.006 & -.022 & -.067 & .010 & -.079 & $.174 * * *$ & -.037 & $-.125 * *$ \\
\hline Mother Edu. & -.010 & .001 & .063 & .015 & .055 & .077 & $.136 *$ & .109 & .023 \\
\hline Father Edu. & $-.129 *$ & -.021 & -.017 & $-.140 *$ & -.014 & $-.143 *$ & .018 & -.069 & $.118^{*}$ \\
\hline Having Sibl. & .049 & .044 & -.084 & .006 & .022 & -.003 & $-.147 * *$ & $-.157 * *$ & $-.142 * *$ \\
\hline Having a Comp. & -.109 & -.060 & $-.146 * *$ & -.084 & -.068 & -.018 & -.004 & -.081 & -.060 \\
\hline Academic Ach. & .049 & -.031 & -.074 & .093 & .003 & -.010 & -.076 & $-.182 * * *$ & $-.219 * * *$ \\
\hline $\mathbf{R}^{2}$ & $.055 *$ & $.033^{*}$ & $.068 * * *$ & $.079 * * *$ & $.030 *$ & $.039 *$ & $.142 * * *$ & $.082 * * *$ & $.108 * * *$ \\
\hline Total $\mathbf{R}^{2}$ & $7.4 \% * *$ & $3.4 \% *$ & $6.9 \% * * *$ & $11.1 \% * * *$ & $3.1 \% *$ & $4 \% *$ & $18.2 \% * *$ & $11.4 \% * * *$ & $13.2 \% * * *$ \\
\hline
\end{tabular}

In Table 2, in the second column, only one predictor blocks accounted for 3.4\% of IMTA variance and $3.3 \%$ of demographic characteristics. Only one block accounted for a significant amount or increment in explained variance of IMTA. Among the demographic predictor variables only school type accounted for a statistically significant portion of IMTA variance. Communal mastery variable did not account for a statistically significant portion of IMTA variance.

In the third column, similarly, only one predictor blocks accounted for $6.9 \%$ of IMES variance and $6.8 \%$ of demographic characteristics. Only one block accounted for a significant amount or increment in explained variance of IMES. Among the demographic predictor variables only school type and having a computer accounted for a statistically significant portion of IMES variance. The communal mastery variable did not account for a statistically significant portion of IMES variance.

In the fourth column, all two predictor blocks accounted for $11.1 \%$ of EMER variance. The predictor blocks separately accounted for the following percentages of EMER: $3.2 \%$ by communal mastery and $7.9 \%$ by demographic characteristics. Of all demographic predictor variables, school type and father's education variables accounted for a statistically significant portion of EMER variance.

In the fifth column, only one predictor blocks accounted for 3.1\% of EMIN variance; demographic characteristics $3 \%$. Only one block accounted for a significant amount or increment in explained variance of EMIN. Among the demographic predictor variables only school type accounted for a statistically significant portion of EMIN variance. Communal mastery variable did not account for a statistically significant portion of EMIN variance.

In the sixth column, only one predictor blocks accounted for $4 \%$ of EMID variance; $3.9 \%$ of demographic characteristics. Only one block accounted for a significant amount or increment in explained variance of EMID. Among the demographic predictor variables only the father's education level accounted for a statistically significant portion of EMID variance. The communal mastery variable did not account for a statistically significant portion of EMID variance.

In the seventh column, all three predictor blocks accounted for $18.2 \%$ of AMOT variance. The predictor blocks separately accounted for the following percentages of AMOT variance: $4 \%$ by communal mastery and $14.2 \%$ by demographic characteristics. Of all the demographic predictor variables, the variables related to gender, school type, mother's education level and having sister or brother variables accounted for a statistically significant portion of AMOT variance.

In the eighth column, all two predictor blocks accounted for $11.4 \%$ of worry variance. The predictor blocks separately accounted for the following percentages of worry variance: $3.2 \%$ by communal mastery, and $8.2 \%$ by demographic characteristics. Of all the demographic predictor variables, the variables of having sister or brother and academic achievement variables accounted for a statistically significant portion of worry variance.

In the ninth column, all two predictor blocks accounted for $13.2 \%$ of emotionality variance. The predictor blocks 
separately accounted for the following percentages of emotionality variance: $2.4 \%$ by communal mastery, and $10.8 \%$ by demographic characteristics. Of all the demographic predictor variables, the variables related to gender, school type, and father's education level, having sister or brother and academic achievement variables accounted for a statistically significant portion of emotionality variance. These results confirmed the third research question. The relative size of the beta weights suggested that communal mastery and demographic characteristics are powerful predictors of both academic motivation and test anxiety.

Table 2 summarizes the beta weights as well. Beta weights provide an appropriate criterion since unlike the percentage of variance $\left(\mathrm{R}^{2}\right)$, beta weights do not change when the order of predictor blocks changes. The relative importance of variables in each predictor block was determined by examining significant beta. The absolute magnitude of beta coefficients indicates the relative strength of seven variables as predictors of academic motivation and test anxiety.

The beta weights for the predictor blocks, including the communal mastery and demographic characteristics as predictors for academic motivation and test anxiety subscales respectively. The comparison of beta magnitude in Table 2 suggests that communal mastery is a salient predictor of both academic motivation and test anxiety subscales. Most beta weights of communal mastery were statistically significant and ranged from 0.137 to 0.200 for academic motivation and test anxiety subscales. Demographic characteristics also mostly had statistically significant beta values for academic motivation and test anxiety ranging from 0.096 to 0.182 . Gender as a predictor variable was positively correlated with beta weight; 0.174 for AMOT and negatively correlated with beta weight; -0.125 for emotionality subtest. School type, mostly positively correlated with beta weights; 0.110 for IMTA subtest, 0.182 for IMES subtest, 0.105 for EMIN subtest, 0.140 for the AMOT subtest and 0.096 for the emotionality subtest. School type only had statistically significant and negative beta weight for EMER at -0.111 . The mother's educational level only had statistically significant and positive beta weight for EMER at 0.136. The father's education level had statistically significant and negative beta weights for three sub-scores of academic motivation; -0.129 for IMTK, -0.140 for EMER and 0.143 for EMID. The father's education level only had statistically significant and positive beta weight for emotionality subscore at 0.118 . Another independed variable; having sisters or brothers had statistically significant and negative beta weights for AMOT at -0.147 , for worry at -0.157 and for emotionality at -0.142 . Having a computer had only one statistically significant and negative beta weight for IMES at -0.146 . Being successful had statistically significant and negative beta weights for worry at -0.182 and for emotionality -0.219 . These results confirmed the importance of communal mastery and demographic characteristics as a predictor. The relative size of the beta weights suggests that both communal mastery and demographic characteristics are powerful predictors of academic motivation and test anxiety.

\section{Discussion and Conclusion}

Academic motivation and test anxiety are foremost problems in education. They are regarded as important subjects in the field of educational psychology research. Examination of motivational factors in academic contexts within self-determination theory has a primarily important role to increase academic achievement in schools. Determination of the risk factors that affect students' academic motivation and test anxiety may lead to preventions for poor academic achievement. The current study intended to examine the impacts of demographic factors and communal mastery on academic motivation and test anxiety levels of students in the based on Deci and Ryan's (1985) self-determination theory.

Results of the analysis provided clear support for five hypotheses relating to academic motivation and test anxiety. First, that communal mastery had a positive relationship with two academic motivation subscales and a negative relationship with only one (AMOT) subscale. Second, that communal mastery had a mostly positive relationship to test anxiety. Third, those demographic characteristics had seven positive and twelve negative relationships to academic motivation subscales. Fourth, those demographic characteristics had positive and negative relationship to test anxiety subscales. Fifth, those demographic variables were important predictors of academic motivation and test anxiety after communal mastery. The current findings suggest that communal mastery and demographic characteristics of students such as the parent education levels, having good conditions at home play an important role in academic motivation.

Communal mastery was related to one intrinsic motivation (to know), one extrinsic motivation (external regulation) and amotivation. Additionally, it was related test anxiety. Communal mastery was found as a significant predictor for three types academic motivation and test anxiety as expected. In Piko's (2006) study, communal mastery was determined as an important factor for adolescents' habits. Similarly, in this study communal mastery was found as an important predictor of academic motivation and test anxiety.

It was reported that motivation levels of university students are affected by a group of demographic characteristics such as, their reason to choose the school, the probability of finding a job after graduation, order of preferences, future expectations, distinctive power of testing and measurement activities at school and their desire to pursue a master's 
degree, the probability of finding a job, attitude towards the teacher, social circle, level of income, appropriateness of the classrooms, efficiency of the educational material and number of siblings (Çeliköz, 2009). Results of similar studies with different groups showed that academic motivation levels were affected by demographic characteristics (Karagüven \& Yükseloglu, 2013; Yükseloglu \& Karagüven, 2013). This study's findings provide support for the view that demographic characteristics are important for academic motivation and test anxiety.

Gender differences are examined in order to reveal differences among boys and girls. Previous studies revealed that, there are relatively differences in motivation and academic performance in between sexes (House, 1997). The current study found that gender was negatively related to one extrinsic motivation (external regulation) and positively related to amotivation.

Parental education levels and having siblings were also examined and the results resembled prior studies. The parental education level was studied with academic performance by Tavani and Losh (2003) and was found to be an important factor for students' academic performance.

Some facilities such as having a computer can be a motivating factor for students. Adequate educational materials (e.g., a computer) provide a platform for effective studying at home and at school, and can motivate students to study. Governmental initiatives should provide motivational materials such as computers for student use in schools. Similarly, the relationship between type of motivation (intrinsic or extrinsic) and students' home background (middle-class or upper working-class) was studied by Whitehead (1984). He identified that students' different types of motivations (intrinsic or extrinsic) was caused by differing home backgrounds.

Academic achievement was related to amotivation and test anxiety. These results are consistent with the literature (House, 1997; Khalaila, 2014). House's (1997) study found that students' academic performances and motivations are significantly related to one another. Achievement motivation was positively associated with academic success (Busato, et al., 2000). Motivation and test anxiety were significant predictors for chemistry achievement (Akbas \& Kan, 2007). These results are supported by this study, demonstrating not a strong but a negative relationship between students' amotivations levels and perceived academic achievement as it is expected. This finding was similar with the study of Jurisevic et al. (2008), the results of which were related to the level of the pre-service primary school teachers' intrinsic motivation for learning science. The correlation between the level of motivation and the knowledge test results is not strong; nevertheless, it is statistically significant (Jurisevic et al., 2008). On the other hand, Renchler (1992) examined academic achievement and motivation among American high-school students, who had A averages, and the results indicated that their level of motivation was not particularly high. According to the statistical results of this study, academic achievement was not related to intrinsic and extrinsic motivations, and perceived academic achievement was not a predictor for motivation. On the other hand, test anxiety emerged as the best predictors of perceived academic achievement, as was the case in Pintrich, and De Groot's (1990) study. They found that, test anxiety was the best predictors of academic performance.

In terms of motivational theory, the motivational profiles of these students seemed to be well captured within the framework of self-determination theory (Deci \& Ryan, 1985; 1991) by drawing attention to the factors that had an effect on academic motivation. This study contributes to the literature on motivation in education. The study confirmed that students' academic motivation is affected by different factors. Findings provide support for the view that demographic characteristics affect academic motivation and test anxiety.

Consequently, academic motivation and test anxiety levels of students are affected by different factors such as; communal mastery, gender, school type, parents' level of education, having siblings, having a computer at home and academic achievement. These results revealed that communal mastery, and demographic characteristics are important factors for academic motivation and test anxiety. In other words, academic motivation and test anxiety predicted by communal mastery and demographic characteristics such as parents' level of education, having a sister or brother, and the level of academic achievement perception about herself or himself. Although, the relative importance of these factors as predictors, at least for a group of high-school students, these results should not be underestimated. Despite some findings about the teachers' beliefs that the motivation of at least, some student is outside of their control (Hardré \& Sullivan, 2009; Thoonen, Sleegers, Peetsma \& Oort, 2011), to prevent negative psychological effects of motivational problems on academic achievement, motivational factors should be used by teachers and parents. Academic performances may increase at all levels of education by raising academic motivation and controlling test anxiety levels of students.

Although, this study has aided in providing additional knowledge and insight into some of the key predictors of test anxiety and academic motivation, there are several strengths and limitations. One of its strengths was the sample size of the study. The use of standardized measures and procedures was the other strength. The weaknesses were typical of many published studies. Many of the items included in the questionnaire measuring motivation and communal mastery 
were objective situations or actions. Conversely, the test anxiety scale was largely comprised of subjective ratings of subjective experiences.

To gain a greater understanding of the risk factors involved, subsequent studies of academic motivation and test anxiety should examine not only demographic characteristics and communal mastery but also different factors. Thus, replication attempts should involve not only students but also teachers, different populations, longitudinal designs and appropriate control groups. Replication with different subjects in order to determine the influence of different contexts on students' academic motivation is necessary to increase confidence before making generalizing about other populations.

\section{References}

Aksan, M., \& Koçyiğit, M. (2011). Research report for 2009-2010 years about the reasons for poor academic performance of primary and secondary school studens of Amasya Guidance and Councelling center. Retrieved February 9, 2014, from http://okulweb.meb.gov.tr/05/01/117498/haberduyuru/rehberlik/bna_degerlendirme.

Atkinson, J. W., \& Feather, N. T. (1964). A Theory of Achievement Motivation. New York: Wiley Ltd.

Atkinson, J. W. (1964). An Introduction to Motivation. Princeton: Van Nostrand.

Balogun, A. G. (2014). Effect of Test Anxiety on Academic Performance: Achievement Motivation as a Buffer. Universal Journal of Educational Research, 2(8), 531-536. http://dx.doi.org/10.13189/ujer.2014.020801

Bandura, A. (1997). Self-efficacy: the exercise of control. New York: Freeman.

Barron, K. E., \& Harackiewicz, J. M. (2001). Achievement goals and optimal motivation: testing multiple goal models. Journal of Personality and Social Psychology, 80, 706-722. http://dx.doi.org/10.1037/0022-3514.80.5.706

Bembenutty, H., McKeachie, W. J., Karabenick, S. A., \& Lin, Y. (1998). The relationship between test anxiety and self-regulation on students' motivation and learning. Paper presented at the annual meeting of the American Psychological Society, Washington, DC.

Boekaerts, M. (1996). Personality and the psychology of learning. European Journal of Personality, 10, 377-404. http://dx.doi.org/10.1002/(SICI)1099-0984(199612)10:5<377::AID-PER261>3.0.CO;2-N

Busato, V. V., Prins, F. J., Elshout, J. J., \& Hamaker, C. (2000). Intellectual ability, learning style, personality, achievement motivation and academic success of psychology students in higher education. Personality and Individual Differences, 29, 1057-1068. http://dx.doi.org/10.1016/S0191-8869(99)00253-6

Çeliköz, N. (2009). An analysis of pre-school teachers' and teachers' attitudes to inclusion and their self-efficacy. International Journal of Special Education, 24(3), 29-44.

Daft, R. L. (1997). Management. Orlando, Fl.: Harcourt Brace, (4th ed.), 526.

Deci, E. L., Vallerand, R. J., Pelletier, L G., \& Ryan, R. M. (1991). Motivation and education: the self-determination perspective. Educational Psychologist, 26, 325-346. http://dx.doi.org/10.1080/00461520.1991.9653137

Deci, E. L. (1975). Intrinsic Motivation. New York: Plenum Press. http://dx.doi.org/10.1007/978-1-4613-4446-9

Deci, E. L., \& Ryan, R. M. (1985). Intrinsic Motivation and Self-Determination in Human Behavior. New York: Plenum Press. http://dx.doi.org/10.1007/978-1-4899-2271-7

Deci, E. L., \& Ryan, R. M. (2000). The what and why of goal pursuits: human needs and the self-determination of behavior. Psychological Inquiry, 11, 227-268. http://dx.doi.org/10.1207/S15327965PLI1104_01

Drich, P. R., \& De Groot, E. V. (1990). Motivational and self-regulated learning components of classroom academic performance. Journal of Educational Psychology, 82, 33-40. http://dx.doi.org/10.1037/0022-0663.82.1.33

Elliot, A. J., \& Thrash, T. M. (2001). Achievement goals and the hierarchical model of achievement motivation. Educational Psychology Review, 13, 139-156. http://dx.doi.org/10.1037/0033-295x.95.2.256

Entwistle, N. J. (1968). Academic motivation and school attainment. British Journal of Educational Psychology, 38, 181-188. http://dx.doi.org/10.1111/j.2044-8279.1970.tb02113.x

Erdogan, A., Kesici, S., \& Sahin, I. (2011). Prediction of high school students' mathematics anxiety by their achievement motivation and social comparison. Elementary Education Online, 10(2), 646-652.

Ergene, T. (2011). The relationships among test anxiety, study habits, achievement motivation, and academic performance among Turkish high-school students. Education and Science, 36, 160-167.

Eysenck, H. J. (1970). The structure of human personality. (3rd ed.). London: Methuen.

Eysenck, M., \& Calvo, M. G. (1992). Anxiety and performance: The processing efficiency theory. Cognition and 
Emotion. 6, 409-434. http://dx.doi.org/10.1080/02699939208409696

Eysenck, M. W. (1992). Anxiety: The Cognitive Perspective. Hove, UK: Lawrence Erlbaum.

Francis, A., Goheer, A., Haver-Dieter, R., Kaplan, A. D., Kerstetter, K., \& Kirk, A. L. (2004). Promoting academic achievement and motivation: a discussion and contemporary issues based approach. Retrieved November 19, 2014, from http://Achievement_and_Motivation-_A_Discussion_\%26_Contemporary_Issues

Frymier, J. R. (1975). A longitudinal study of academic motivation. The Journal of Educational Research, 69, 2. http://dx.doi.org/10.1080/00220671.1975.10884831

Georgiou, S. N. (1999). Parental attributions as predictors of involvement and influences on child achievement. British Journal of Educational Psychology, 69, 409-429. http://dx.doi.org/10.1348/000709999157806

Grolnick, W. S., \& Ryan, R. M. (1989). Parent styles associated with children's self-regulation and competence in school. Journal of Educational Psychology, 81, 143-154. http://dx.doi.org/10.1037/0022-0663.81.2.143

Hagtvet, K. A., \& Benson, J. (1997). The motive to avoid failure and test anxiety responses: empirical support for integration of two research traditions. Anxiety, Stress and Coping: An International Journal 10, 35-57. http://dx.doi.org/10.1080/10615809708249294

Hancock, D. R. (2001). Effects of test anxiety and evaluative threat on students' achievement and motivation. The Journal of Educational Research, 94, 284-290. http://dx.doi.org/10.1080/00220670109598764

Hardre, P. R., \& Sullivan, D. V. (2009). Motivating adolescents: high-school teachers' perceptions and classroom practices. Teacher Development: An International Journal of Teachers' Professional Development, 13, 1-16. http://dx.doi.org/10.1080/13664530902858469

Harris, D. (1940). Factors affecting college grades: a review of the literature: 1930-1937. Psychological Bulletin, 37, 125-166. http://dx.doi.org/10.1037/h0055365

Hobfoll, S. E., Jackson, A., Hobfoll, I., Pierce, C. A., \& Young, S. (2002). The impact of communal-mastery versus self-mastery on emotional outcomes during stressful conditions: a prospective study of Native American women. American Journal of Community Psychology, 30, 853-871. http://dx.doi.org/10.1023/A:1020209220214

Hobfoll, S. E., Schröder, K. E. E., Wells, M., \& Malek, C. (2002). Communal versus individualistic construction of sense of mastery in facing life challenges. Journal of Social and Clinical Psychology, 21, 362-399. http://dx.doi.org/10.1521/jscp.21.4.362.22596

House, E. R. (1993). Professional evaluation: Social impact and political consequences. Newbury Park, CA: Sage.

House, J. D. (1997). The relationship between self-beliefs, academic background, and achievement of adolescent Asian-American students. Child Study Journal, 27, 95-109.

Howey, S. C. (2008). Factors in student motivation. Retrieved July 6, 2014, from http://www.nacada.ksu.edu/Clearinghouse/AdvisingIssues/Motivation.htm

Hürsen, Ç., \& Tekman, İ. (2014). Determination of students' general test anxiety and their test anxiety concerning English classes. Cpriot Journal of Educational Sciences. 9(4), 251-269. Retrieved from file:///C:/Users/MH\%C3\%9CLYA/Downloads/3502-12547-1-PB.pdf

Jurisevic, M., Glazar, S. A., Pucko, R. C., \& Devetak, I. (2008). Intrinsic motivation of pre-service primary school teachers for learning chemistry in relation to their academic achievement, International Journal of Science Education, 30, 87-107. http://dx.doi.org/10.1039/b920833j

Karagüven, M. H., \& Yükseloğlu, M. (2013). Vocational self-efficacy and academic motivation levels of technical and vocational pre-service teachers (example of Marmara University). Proceedings of the $4^{\text {th }}$ International Conference on New Horizons in Education-INTE, 106, 3366-3374. http://dx.doi.org/10.1016/j.sbspro.2013.12.389

Khalaila, R., (2014). The relationship between academic self-concept, intrinsic motivation, test anxiety, and academic achievement among nursing student, Nurse Education Today, In press http://dx.doi.org/10.1016/j.nedt.2014.11.001

Liebert, R., \& Morris, L. (1967). Cognitive and emotional components of test anxiety: A distinction and some initial data. Psychological Reports, 20, 975-978. http://dx.doi.org/10.2466/pr0.1967.20.3.975

McClelland, D. C., Atkinson, J. W., Clark, R. A., \& Lowell, F. L. (1953). The Achievement Motive. New York: Appleton-Century-Crofts. http://dx.doi.org/10.1037/11144-000

Miserandino, M. (1996). Children who do well in school: individual differences in perceived competence and autonomy in above average children. Journal of Educational Psychology, 88, 203-214. 
http://dx.doi.org/10.1037/0022-0663.88.2.203

Oliver, J. S., \& Simpson. R. D. (1988). Influences of attitude toward science, achievement motivation and science self-concept on achievement in science: a longitudinal study. Science Education, 72, 143-155. http://dx.doi.org/10.1002/sce.3730720204

Öner, N. (1990). Sinav Kaygısı Envanteri El Kitabı. İstanbul: Yöret, Turkey.

Pearlin, L. I., Lieberman, M. A. Menaghan, E. G., \& Mullan, J. T. (1981). The stress process. Journal of Health and Social Behavior, 22, 337-356. http://dx.doi.org/10.2307/2136676

Pekrun, R., T., Goetz, R. P., Perry, K., Kramer, M., Hochstadt, S., \& Molfenter, S. (2004). Beyond test anxiety: development of the test emotions questionnaire (TEQ). Anxiety, Stress and Coping: An International Journal, 17, 287-316. http://dx.doi.org/10.1080/10615800412331303847

Piko, B. F. (2006). Adolescent smoking and drinking: the role of communal mastery and other social influences. Addictive Behaviors, 31, 102-114. http://dx.doi.org/10.1080/00207590903030279

Pintrich, P. R., \& De Groot, E. V. (1990). Motivational and self-regulated learning components of classroom academic performance. Journal of Educational Psychology, 82, 33-40. http://dx.doi.org/10.1037/0022-0663.82.1.33

Pintrich, P. R., \& Schunk, D. H. (2002). Motivation in Education: Theory, Research, and Applications. New Jersey: Prentice Hall.

Putwain, D. W. (2008). Deconstructing test anxiety. Emotional and Behavioral Difficulties, 13, 141-155. http://dx.doi.org/10.1080/13632750802027713

Renchler, R. (1992). Student motivation, school culture, and academic achievement. ERIC/CEM Trends and Issues Series, 7, USA.

Roeser, R. W., Strobel, K. R., \& Quihuis G. (2002). Studying early adolescents' academic motivation, social-emotional functioning, and engagement in learning: variable- and person-centered approaches. Anxiety, Stress and Coping: An International Journal, 15, 345-367. http://dx.doi.org/10.1080/1061580021000056519

Ryan, R. M., \& Deci E. L. (2000). Self-determination theory and the facilitation of intrinsic motivation, social development, and well-being. American Psychologist, 55, 68-77. http://dx.doi.org/10.1037/0003-066X.55.1.68

Sarason, I. G. (1984). Stress, anxiety, and cognitive interference: Reactions to tests. Journal of Personality and Social Psychology, 44, 929-938. http://dx.doi.org/10.1037/0022-3514.46.4.929

Schwarzer, R. (1993). Measurement of Perceived Self-Efficacy: Psychometric Scales for Cross-Cultural Research. Berlin: Freie Universitat.

Simons, R. H., \& Bibb. J. R. (1974). Achievement motivation, text anxiety, and underachievement in the elementary school. The Journal of Educational Research, 67, 366-369. http://dx.doi.org/10.1080/00220671.1974.10884657

Speilberger, C. D. (1980). Preliminary Professional Manual for the Test Anxiety Inventory. C. A: Consulting Psychologist Press.

Spielberger, C. D. (1979). Understanding Stress and Anxiety. New York: Harper.

Stöber, J., \& Pekrun, R. (2004). Advances in test anxiety research, Anxiety, Stress and Coping: An International Journal, $17,205-211$.

Stöber, J. (2004). Dimensions of test anxiety: relations to ways of coping with pre-exam anxiety and uncertainty. Anxiety, Stress, and Coping, an International Journal, 17, 213-226. http://dx.doi.org/10.1080/10615800412331292615

Thorkildsen, T. A., Nicholls, J. G., Bates, A., Brankis, N., \& DeBolt, T. (2002). Motivation and the Struggle To Learn: Responding To Fractured Experiences. Boston, Massachusetts: Allyn and Bacon.

Thoonen, E. E. J., Sleegers, P. J. C., Peetsma, T. D. D., \& Oort F. J. (2011). Can teachers motivate students to learn? Educational Studies, 37, 345-360. http://dx.doi.org/10.1080/03055698.2010.507008

Tucker, C. M., Zayco, R. A., \& Herman, K. C. (2002). Teacher child variables as predictors of academic engagement among low-income African American children. Psychology in the School, 39, 477-488. http://dx.doi.org/10.1002/pits.10038

Ünal-Karagüven, M. H. (2005). Communal mastery levels of technical high-school students. Paper presented at the annual meeting for $25^{\text {th }}$ International Stress and Anxiety Research Conferance, Germany, July 21-23. Retrieved from http://www.star-society.org/html/conferences.html 
Ünal-Karagüven, M. H. (2012). The adaptation of academic motivation scale to Turkish. Educational Sciences: Theory and Practice, 12, 2599-2620.

Ünal-Karagüven, M. H., \& Gül, C. (2013, May). Psychometric properties of Turkish form of the communal-mastery scale. Poster presented at the International Conference Psychology Education, Guidance and Counseling-ICPEG, Istanbul, $\quad$ Turkey. Retrieved from http://www.turkpdristanbul.com/icpeg-2013-turkce-international-conference-psychology-education-guidance-coun selling/

Uzbas, A. (2009). Okul psikolojik danışmanlarının okulda saldırganlık ve şiddete yönelik görüşlerinin değerlendirilmesi. Mehmet Akif Ersoy Üniversitesi, Eğitim Fakültesi Dergisi, 18, 90-110.

Vallerand, R. J., Pelletier, L. G., Blais, M. R., Brière, N. M., Senécal, C., \& Vallières, E. F. (1992). The academic motivation scale: a measure of intrinsic, extrinsic, and amotivation in education. Educational and Psychological Measurement, 52, 1003-1017. http://dx.doi.org/10.1177/0013164492052004025

Vansteenkiste, M., Lens, W., \& Deci, E. L. (2006). Intrinsic versus extrinsic goal contents in self-determination theory: Another look at the quality of academic motivation. Educational Psychologist, 41, 19-31. http://dx.doi.org/10.1207/s15326985ep4101_4

Whitehead, J. (1984). Motives for higher education: A study of intrinsic and extrinsic motivation in relation to academic attainment. Cambridge Journal of Education, 14, 26-34. http://dx.doi.org/10.1080/0305764840140204

Woolfolk, A. E. (2004). Educational Psychology. New York: Pearson Press.

Yıldırım, İ. (2000). Akademik başarının yordayıcısı olarak yalnızlık, sınav kaygısı ve sosyal destek. Hacettepe Üniversitesi Eğitim Fakültesi Dergisi, 18, 167-176.

Yükseloğlu, M., \& Karagüven, M. H. (2013). Academic motivation levels of high-school students. Proceedings of the $4^{\text {th }}$ International Conference on New Horizons in Education-INTE, 106, 282-288. http://dx.doi.org/10.1016/j.sbspro.2013.12.033

Tavani, C. M., \& Losh, S. C. (2003). Motivation, self-confidence, and expectations as predictors of the academic performances among our high-school students, Child Study Journal, 33, 141-151.

This work is licensed under a Creative Commons Attribution 3.0 License. 